11. Россихіна-Галича $\boldsymbol{\Gamma}$. С. Прооксидантно-антиоксидантна рівновага насіння Fraxinus excelsior L. в умовах міського середовища. Вісник Львів. ун-ту. Серія біологічна. 2013. Вип. 61. С. 195-200.

12. Хромих Н. О. та ін. Сезонна динаміка антиоксидантних процесів у листках Acer negundo за дії полютантів. Вісник Дніпропетр. ун-ту. Серія. Біологя, екологія. 2014. № 22 (1). С. 71-76.

13. Таран Н. Ю., Оканенко О.А., Бацманова Л.М. Вторинний оксидний стрес як елемент загальної адаптивної відповіді рослин на дію несприятливих факторів довкілля.

Физиология и биохимия культурных растений. 2004. Т. 36. № 1. С. 3-14.

Надійила до редколегії 30.11.2017

УДК 581.44](477.63)

3. В. Грицай, А. В. Наливайченко

Дніпровський національний університет імені Олеся Гончара

\title{
ВПЛИВ ВИКИДІВ ПРИДНІПРОВСЬКОЇ ТЕС М. ДНІПРО НА АНАТОМІЧНІ ПОКАЗНИКИ СТЕБЛА ОДНОРІЧНОГО ПАГОНА ПРЕДСТАВНИКІВ РОДУ $A C E R$
}

Наведено результати дослідження впливу хронічного забруднення довкілля викидами Придніпровської ТЕС м. Дніпро на анатомічні показники стебла однорічного пагона представників роду Acer. У вивчених об'сктів на техногенно забрудненій ділянці встановлено зміни розмірів гістологічних елементів стебла, характер яких має видові відмінності. У A. pseudoplatanus за дії токсичних викидів ТЕС виявлено збільшення ширини первинної кори стебла й окремих її складових (корку, коленхіми, корової паренхіми) та підтримання стабільних розмірів вторинної кори, ії гістологічних елементів (твердого й м'якого лубу), також деревини, що ми розглядаємо як показники відносної стійкості даного виду в техногенному середовищі. У $A$. platanoides за дії токсикантів встановлено збільшення ширини корку, корової паренхіми й загальної товщини первинної кори, що може забезпечувати певну толерантність рослин за несприятливих умов. Разом з тим у A. platanoides у забрудненій зоні виявлено зменшення розмірів коленхіми, твердого лубу, м'якого лубу, шо в сукупності може зменшувати механічну міцність стебла, порушувати пересування розчинів органічних речовин по системі спеціалізованих провідних тканин, $\mathbf{i}$, таким чином, підвищувати вразливість рослин даного виду на техногенних територіях. Надано рекомендації щодо залучення досліджених видів р. Acer до озеленення промислових зон в умовах Степового Придніпров'я.

Ключові слова: техногенне забруднення; види роду Acer; первинна кора; луб; деревина; серцевина.

3. В. Грицай, А. В. Наливайченко

Днепропетровский национальный университет имени Олеся Гончара

\section{ВЛИЯНИЕ ВЫБРОСОВ ПРИДНЕПРОВСКОЙ ТЭС Г. ДНЕПР НА АНАТОМИЧЕСКИЕ ПОКАЗАТЕЛИ СТЕБЛЯ ГОДИЧНОГО ПОБЕГА ПРЕДСТАВИТЕЛЕЙ РОДА $A C E R$}

Приведены результаты исследования влияния хронического загрязнения окружающей среды выбросами Приднепровской ТЭС г. Днепр на анатомические показатели стебля годичного побега представителей рода Acer. У изученных объектов на техногенно загрязненном участке установлены изменения размеров гистологических элементов стебля, характер которых имеет видовые различия. У $A$.pseudoplatanus

(C) 3. В. Грицай, А. В. Наливайченко, 2017 
при воздействии токсических выбросов ТЭС выявлено увеличение ширины первичной коры стебля и отдельных ее составляющих (пробки, колленхимы, коровой паренхимы) и сохранение стабильных размеров вторичной коры, ее гистологических элементов (твердого и мягкого луба), также древесины, что мы рассматриваем как показатели относительной устойчивости данного вида в техногенной среде. У A. platanoides при воздействии токсикантов установлено увеличение ширины пробки, коровой паренхимы и общей толщины первичной коры, что может обеспечивать определенную толерантность растений в неблагоприятных условиях. Вместе с тем у A. platanoides в загрязненной зоне выявлено уменьшение размеров колленхимы, твердого луба, мягкого луба, что в совокупности может ухудшать механическую прочность стебля, нарушать передвижение растворов органических веществ по системе специализированных проводящих тканей, и, таким образом, повышать уязвимость растений данного вида на техногенных территориях. Даны рекомендации по привлечению исследованных видов рода Acer к озеленению промышленных зон в условиях Степного Приднепровья.

Ключевые слова: техногенное загрязнение; виды рода Acer; первичная кора; луб; древесина; сердцевина.

\author{
Z. V. Gritsay, A. V. Nalivaichenko \\ Oles' Honchar Dnipro National University
}

\title{
INFLUENCE OF EMISSIONS OF PRYDNIPROVSKA TPP IN THE CITY OF DNIPRO ON ANATOMIC INDICATORS OF THE STEM OF ONE-YEAR SHOOTS OF ACER GENDER REPRESENTATIVES
}

The paper presents the results of the study of the influence of chronic pollution of the environment by the emissions of the Prydniprovskaya TPP of the Dnipro River on the anatomical indices of the stem of the one-year shoots of the representatives of Acer genus.

The research objects are Acer platanoides L., A. pseudoplatanus L. The samples are taken in October 2017 at two monitoring points: the test area, formed by tree plantation adjacent to the Prydniprovska TPP, Dnipro, in which emissions of major pollutants such as sulfur dioxide, nitrogen oxides and solid impurities make 67,3\%, 18,7 \%, and 13,3 \% respectively in the total emissions volume; and the relatively clean reference area, which is the Botanical Garden of Dniprovsk National University named after O.Honchar.

For the study, one-year apical shoots were taken from the branches of the same order of branching. The cut was made on the middle transverse line of the stem. The cut was coloured with phloroglucine alcohol solution. Dimensions of the histological elements of the stem were measured under a microscope using an ocular micrometer with an increase of $7 \times 40(0,65)$. Repeat experiment -30 slicers for each species from each test area. In the investigated objects on the technogenically contaminated site, there were changes in the size of the histological elements of the stem, the nature of which has species differences.

In A. pseudoplatanus, due to the action of toxic emissions of TPP, there is an increase in the width of the primary cortex of the stem and its individual components (cork, collenchyma, cortex parenchyma) and the maintenance of stable sizes of the secondary cortex, its histological elements (hard and soft bark), and wood, which we consider as indicators of the relative stability of this species in an industrial environment. In A. platanoides, the effect of toxicants resulted in an increase in the width of the cork, the cortex parenchyma and the total thickness of the primary cortex, which can provide a certain tolerance of plants under adverse conditions.

However, A. platanoides in the contaminated area revealed a reduction in the size of collenchyma, hard bast, soft bast, wood, which in aggregate can reduce the mechanical strength of the stem, violate the movement of organic substances in the system of specialized conductive tissues, and thus, to increase the vulnerability of plants of this species in man-made territories. Recommendations on the use of species of the Acer species in the green improvement of an industrial city in the conditions of the steppe Prydniprovya are given.

Keywords: man-made pollution; species of Acer genus; primary cortex; bast; wood; pith. 
Одним із найбільших мегаполісів України є м. Дніпро. Серед усіх сконцентрованих на його території підприємств різного профілю надзвичайно велику частку шкідливих сполук у повітряний басейн міста вносить Придніпровська ТЕС [8].

В оптимізації міського середовища 3 високим рівнем техногенного забруднення суттєва роль належить створенню зелених зон із використанням деревних порід [3; 13]. Проте слід враховувати, що рослини, виконуючи очистну функцію, піддаються негативній дії шкідливих речовин, наслідком чого $є$ пригнічення процесів їхнього росту та розвитку [4-6; $11 ; 15-18]$. Загострення проблеми деградації деревних насаджень внаслідок посилення антропогенного впливу в останні десятиріччя відзначається в роботах багатьох авторів [2; 14-18].

У системі зеленого будівництва важливе місце належить видам роду Acer. Однак широке залучення кленів до зеленого благоустрою техногенно забруднених зон потребує врахування їх толерантності в конкретних екологічних умовах [7; 13]. Підбираючи асортимент видів для озеленення територій з високим рівнем антропогенного навантаження, необхідно, зокрема, враховувати здатність рослин поглинати шкідливі сполуки, зберігаючи при цьому свої естетичні якості, а також їх стійкість за конкретних умов поєднання відповідних природних i антропогенних чинників [7]. Одним із критеріїв фізіологічного стану рослинного організму є анатомічні показники пагонів, оскільки зміни їх гістологічних характеристик відображують фізіолого-біохімічні та ростові адаптивні процеси рослин [1; 12].

Мета даної роботи - оцінити вплив забруднення довкілля викидами Придніпровської ТЕС м. Дніпро на анатомічні показники стебла однорічного пагона представників роду Acer.

Об'єкти та методи їх дослідження. Об'єкти дослідження - клен гостролистий (Acer platanoides L.), клен несправжньоплатановий (Acer pseudoplatanus L.). Проби відбирали в жовтні 2017 р. у двох точках: дослідна ділянка - деревні насадження, що прилягають до Придніпровської ТЕС м. Дніпро, у викидах якої основними забруднюючими речовинами є діоксид сірки, оксиди азоту, тверді домішки, частка яких до загального обсягу викидів даного об’єкта складає 67,3 \%, 18,7 \%, 13,3 \% відповідно [8]; контрольна ділянка (умовно чиста) - територія Ботанічного саду Дніпровського національного університету ім. Олеся Гончара, де концентрації забруднюючих речовин не перевищують ГДК.

На обох пробних ділянках для кожного виду з декількох модельних дерев відбирали по 30 однорічних верхівкових пагонів із гілок однакового порядку галуження. Фіксацію матеріалу здійснювали в 70 \% етанолі. Поперечні зрізи готували 3 середньої частини стебла однорічного пагона. Для реакції на здерев’яніння зрізи забарвлювали 1 \% спиртовим розчином флороглюцину [9]. Розміри гістологічних елементів стебла вимірювали під мікроскопом за допомогою окуляр-мікрометра при збільшенні 7x40 (0,65). Повторність досліду - 30 зрізів стебла для кожного виду з кожної пробної площі.

Результати експерименту опрацьовано за допомогою стандартних статистичних методів [10]. Розраховували стандартне квадратичне відхилення, стандартну похибку середнього арифметичного. Достовірність відмінності вибірок оцінювали за t-критерієм (Ст'юдента) при р <0,05.

Результати та їх обговорення. За умов хронічної дії на деревні насадження викидів ТЕС у досліджених видів роду Acer виявлено зміни анатомічних показників стебла однорічного пагона.

На поперечному зрізі стебла однорічного пагона зовнішнім шаром тканин $\epsilon$ первинна кора. В обох вивчених видів встановлено збільшення iĭ ширини у дерев, що зазнавали впливу викидів ТЕС, порівняно з контрольними рослинами. Більшою мірою товщина даного шару тканин у дослідному варіанті підвищується в A. pseudoplatanus (на 13,2 \% відносно контролю) (див. табл. 1). 
Таблиия 1

Вплив викидів Придніпровської ТЕС на розміри гістологічних елементів первинної кори стебла однорічного пагона представників роду $\operatorname{Acer}(\mathbf{n = 3 0})$

\begin{tabular}{|c|c|c|c|c|c|}
\hline \multirow{2}{*}{$\begin{array}{c}\text { Гістологічні } \\
\text { елементи }\end{array}$} & \multirow{2}{*}{ Вид } & \multicolumn{2}{|c|}{$\begin{array}{c}\text { Ширина гістологічних елементів } \\
\text { по радіусу поперечного зрізу } \\
\text { стебла, мкм }\end{array}$} & \multirow{2}{*}{$\begin{array}{c}\text { Частка від } \\
\text { контролю, \% }\end{array}$} & \multirow{2}{*}{$\mathrm{t}$} \\
\hline & & $\begin{array}{c}\text { контрольна } \\
\text { ділянка }\end{array}$ & $\begin{array}{c}\text { дослідна } \\
\text { ділянка }\end{array}$ & & \\
\hline \multirow{2}{*}{ Первинна кора } & A. platanoides & $278,6 \pm 1,96$ & $302,7 \pm 2,18$ & 108,7 & 8,23 \\
\hline & A. pseudoplatanus & $516,2 \pm 7,31$ & $584,3 \pm 8,03$ & 113,2 & 6,27 \\
\hline \multirow{2}{*}{ Корок } & A. platanoides & $110,8 \pm 1,94$ & $124,4 \pm 1,62$ & 112,3 & 5,38 \\
\hline & A. pseudoplatanus & $86,6 \pm 1,48$ & $108,7 \pm 1,83$ & 125,5 & 9,39 \\
\hline \multirow{2}{*}{ Коленхіма } & A. platanoides & $80,4 \pm 1,26$ & $71,8 \pm 1,39$ & 89,3 & 4,58 \\
\hline & A. pseudoplatanus & $172,7 \pm 1,93$ & $189,8 \pm 2,07$ & 109,9 & 6,04 \\
\hline \multirow{2}{*}{$\begin{array}{l}\text { Корова } \\
\text { паренхіма }\end{array}$} & A. platanoides & $80,1 \pm 1,17$ & $93,4 \pm 1,36$ & 116,6 & 7,43 \\
\hline & A. pseudoplatanus & $249,0 \pm 2,18$ & $270,1 \pm 2,41$ & 108,5 & 6,49 \\
\hline
\end{tabular}

Примітка: $\mathrm{t}_{0,05} .=2,05$.

Аналіз впливу техногенного навантаження на розміри окремих складових первинної кори стебла свідчить, що за дії токсичних викидів ТЕС у досліджених порід змінюється ширина всіх гістологічних елементів даної покривної тканини. Товщина корку в умовах забруднення збільшується в обох видів (див. табл. 1). Враховуючи захисну функцію фелеми, можна припустити, що збільшення іï розміру в стеблі досліджуваних об'єктів за умов техногенезу може підвищувати захист глибшерозташованих структур зазначеного органа від токсичних хімічних речовин. Наступними після корку шарами первинної кори однорічного стебла кленів є коленхіма та корова паренхіма. За дії токсичних викидів ТЕС у A. pseudoplatanus товщина обох шарів (і механічної тканини, і паренхіми) збільшується порівняно з контрольним варіантом. У A. platanoides розміри коленхіми зменшуються відносно контролю (на 10,7 \%), а корової паренхіми - збільшуються (на 16,6 \%) (див. табл. 1). Вважаємо, що зниження товщини механічної тканини в стеблі A. platanoides у техногенній зоні може зменшувати механічну міцність стебла, що $\epsilon$ додатковим негативним фактором за несприятливих умов зростання.

У досліджуваних органах під первинною залягає вторинна кора. Вона представлена елементами твердого та м'якого лубу. Характер зміни загальної ширини даного шару тканин та розмірів його складових елементів за дії промислових викидів у досліджених порід має видову відмінність. У A. pseudoplatanus практично не відрізняється в рослин контрольної й дослідної ділянок як загальна товщина вторинної кори, так і розміри окремих гістологічних складових флоеми (м'якого та твердого лубу). Відмінність у цих показниках між деревами проммайданчика й умовно чистої зони недостовірна (при Р <0,05) (див. табл. 2). Вважаємо, що утримання стабільних розмірів м'якого лубу в стеблі $A$. pseudoplatanus за умов техногенного впливу дозволить підтримувати на належному рівні пересування розчинів органічних речовин по системі ситоподібних трубок флоеми, а розмірів твердого лубу - зберігати механічну міцність стебла. У A. platanoides на техногенно забрудненій території загальна ширина вторинної кори зменшується (на 12,9 \% відносно контролю). Це відбувається за рахунок зниження товщини як м'якого лубу, так і твердого (на 9,1% та 13,1% порівняно з контролем відповідно) (див. табл. 2). Зменшення розмірів флоемної частини стебла в A. platanoides, яке спостерігається за дії токсичних викидів ТЕС, може спричинювати послаблення транспорту продуктів асиміляції з листків до інших органів і тканин та негативно позначатись на їх фізіологічній діяльності за несприятливих умов зростання. Зниження товщини твердого лубу може погіршувати його опорну функцію в стеблі. 
Таблиия 2

Вплив викидів Придніпровської ТЕС на розміри гістологічних елементів центрального циліндра стебла однорічного пагона представників роду Acer $(\mathrm{n}=30)$

\begin{tabular}{|c|c|c|c|c|c|}
\hline \multirow{2}{*}{$\begin{array}{l}\text { Гістологічні } \\
\text { елементи }\end{array}$} & \multirow[t]{2}{*}{ Вид } & \multicolumn{2}{|c|}{$\begin{array}{c}\text { Ширина гістологічних елементів по } \\
\text { радіусу поперечного зрізу стебла, } \\
\text { мкм } \\
\end{array}$} & \multirow{2}{*}{$\begin{array}{c}\text { Частка від } \\
\text { контролю, \% }\end{array}$} & \multirow[t]{2}{*}{$\mathrm{t}$} \\
\hline & & $\begin{array}{c}\text { контрольна } \\
\text { ділянка }\end{array}$ & дослідна ділянка & & \\
\hline \multirow{2}{*}{ Вторинна кора } & A. platanoides & $196,1 \pm 2,28$ & $170,9 \pm 2,03$ & 87,1 & 8,25 \\
\hline & A.pseudoplatanus & $301,4 \pm 3,76$ & $296,6 \pm 2,92$ & 98,4 & 1,01 \\
\hline \multirow{2}{*}{ Твердий луб } & A.platanoides & $50,3 \pm 1,19$ & $43,7 \pm 1,04$ & 86,9 & 4,18 \\
\hline & A.pseudoplatanus & $70,2 \pm 1,82$ & $67,4 \pm 1,36$ & 96,0 & 1,23 \\
\hline \multirow{2}{*}{ М'який луб } & A. platanoides & $140,7 \pm 1,90$ & $128,0 \pm 1,68$ & 90,9 & 5,01 \\
\hline & A. pseudoplatanus & $243,9 \pm 2,83$ & $237,3 \pm 2,17$ & 97,3 & 1,85 \\
\hline \multirow{2}{*}{ Деревина } & A.platanoides & $440,2 \pm 6,11$ & $420,8 \pm 6,31$ & 95,6 & 2,21 \\
\hline & A.pseudoplatanus & $540,8 \pm 7,63$ & $557,0 \pm 8,24$ & 103,0 & 1,44 \\
\hline \multirow{2}{*}{$\begin{array}{l}\text { Серцевина } \\
\text { (радіус) }\end{array}$} & A.platanoides & $900,3 \pm 13,7$ & $754,2 \pm 11,2$ & 83,8 & 8,25 \\
\hline & A.pseudoplatanus & $1566 \pm 26,2$ & $1403 \pm 23,8$ & 89,6 & 4,62 \\
\hline \multirow{2}{*}{$\begin{array}{l}\text { Стебло в цілому } \\
\text { (радіус) }\end{array}$} & A.platanoides & $1800 \pm 31,6$ & $1679 \pm 28,1$ & 93,3 & 2,87 \\
\hline & A.pseudoplatanus & $2997 \pm 42,9$ & $2892 \pm 36,4$ & 96,5 & 1,86 \\
\hline
\end{tabular}

Примітка: $\mathrm{t}_{0,05}=2,05$.

Розмір деревини за дії викидів ТЕС у A. pseudoplatanus практично не відрізняється від контролю, в A. platanoides - знижується, проте не дуже суттєво (на 4,4 \%) (див. табл. 2), що, вважаємо, дозволить рослинам у техногенному середовищі зберігати на належному рівні пересування води й мінеральних речовин по системі провідних елементів ксилеми та утримувати механічну міцність стебла.

Радіус центральної частини стебла (серцевини) за дії фітотоксикантів зменшується відносно контролю в обох досліджених об'єктах (див. табл. 2).

Висновки. В умовах забруднення довкілля викидами Придніпровської ТЕС у досліджених представників роду Acer встановлено зміни розмірів гістологічних елементів стебла однорічного пагона. У $A$. pseudoplatanus i A. platanoides на техногенній ділянці виявлено збільшення товщини первинної кори. Зміна окремих іiї складових за дії фітотоксикантів має видові відмінності: в A. pseudoplata$n u s$ зростає радіус як захисних тканин кори (корку та коленхіми), так і корової паренхіми; в A. platanoides розмір фелеми й корової паренхіми збільшується, а механічної тканини (коленхіми) - зменшується. Ширина вторинної кори та її окремих гістологічних елементів у $A$. pseudoplatanus в умовах техногенного середовища практично не змінюється відносно контролю, а в A. platanoides за дії викидів TEC зменшується товщина як вторинної кори в цілому, так і окремих ії складових (м'якого й твердого лубу). Розмір деревини стебла на забрудненій ділянці не відрізняється від контролю в A. pseudoplatanus та не дуже суттєво зменшується в A. platanoides. Радіус серцевини за дії фітотоксикантів знижується в обох видів.

Збільшення загального радіусу первинної кори, зокрема, ширини корку й корової паренхіми в обох досліджених видів, а також підтримання стабільних розмірів коленхіми, твердого і м'якого лубу, деревини в A. pseudoplatanus, вважаємо, може бути пов'язано з функціонуванням у тканинах даних видів кленів за умов стресу адаптаційних механізмів, кінцевим результатом яких, зокрема, є зміни анатомічних параметрів стебла, які можуть забезпечити певну толерантність рослин у техногенному середовищі. Разом з тим зменшення ширини коленхіми, твердого й м'якого лубу в стеблі A. platanoides в сукупності може знижувати механічну міцність стебла, порушувати пересування розчинів органічних речовин по сис- 
темі спеціалізованих провідних тканин і, таким чином, підвищувати вразливість рослин даного виду на техногенних територіях.

За сукупністю анатомічних характеристик стебла однорічного пагона із досліджених видів більшу чутливість до впливу техногенних емісій виявляє A. platanoides, толерантність - A. pseudoplatanus.

Вид, що за показниками анатомічної будови стебла однорічного пагона виявив толерантність до техногенних емісій (A. pseudoplatanus), рекомендуємо включити до переліку порід, перспективних для використання в зеленому благоустрої промислового міста в умовах Степового Придніпров'я.

\section{Бібліографічні посилання}

1. Алексеев $\boldsymbol{A}$. $\boldsymbol{C}$. Колебания радиального прироста в древостоях в условиях атмосферного загрязнения. Лесоведение. 1990. Вып. 9. № 1. С. 82-86.

2. Бессонова В. П., Юсыпива Т. И. Семенное возобновление древесных растений и промышленные поллютанты ( $\mathrm{SO}_{2}$ и $\left.\mathrm{NO}_{2}\right)$. Запорожье: Изд-во Запорож. гос. ун-та, 2001. 193 с.

3. Бессонова В. П. Оцінка функціонального стану деревних рослин урбофітоценозу за змінами вуглеводного обміну. Матеріали другої Міжнародн. наук.-практ. конференції «Рослини та урбанізація». Дніпропетровськ, 29-30 листопада 2011. С. 48-52.

4. Грицай 3. В., Денисенко О. Г. Насіннєва продуктивність деревних рослин в умовах забруднення довкілля викидами металургійного підприємства Biсник Дніпропетр. унту. Сер. Біол. Екол. 2011. Т.19. № 2. С. 40-44.

5. Грицай 3. В., Трифонов М.О. Вплив викидів Придніпровської ТЕС м. Дніпропетровськ на показники флоральної сфери представників роду Tilia. Питання Степового лісознавства та лісової рекультивації земель. Дніпропетровськ, 2015. Вип. 44. С. 91-95.

6. Грицай 3. В., Шупранова Л. В. Вплив викидів Придніпровської ТЕС м. Дніпропетровськ на анатомічні показники стебла дворічного пагона представників роду Tilia. Вісник Дніпропетровського ун-ту. Сер. Біол., Екол. 2015. 23(5). С. 230-235.

7. Гришко В. М., Машталер Н.В. Вплив забруднення на формування генеративної сфери деяких видів роду Penstemon schmidel в умовах промислового майданчика гірничозбагачувального підприємства. Інтродукиія рослин. 2009. № 1. С. 73-79.

8. Екологічний паспорт Дніпропетровської області, 2014 URL: http: // www.menr. gov.ua / Dnipropetrovska_ekopasport_2014.pdf

9. Пермяков А. И. Микротехника. Москва: МГУ, 1988. 164 с.

10. Приседський Ю. Г. Статистична обробка результатів біологічних експериментів / Ю.Г. Приседський. Донецьк: ДонНУ, 1999. 210 с.

11. Смит У. Х. Лес и атмосфера / У.Х. Сміт. Москва: Прогресс, 1985. 429 с.

12. Юсипіва T. I. Вплив промислового забруднення на гістологічні показники центрального циліндра стебла видів Fraxinus. Вісник Дніпропетр. ун-ту. Сер. Біол. Екол. 2006. T. 14. № 2. C. 207-213.

13. Jusypiva T.I., Korostylova T. S. Technogenic Impact on Physiological and Cytogenic Indices of Reproductive Organs of Tilia Genus Representatives Technogenic Impact on Physiological and Cytogenic Indices of Reproductive Organs of Tilia Genus Representatives Visn. Dnipropetr. Univ. Ser. Biol. Ekol., 2015, 23(1), 10-14.

14. Capuana M. Heavy metals and woody plants - biotechnologies for phytoremediation. Forest. 2011. 4. P. 7-15.

15. Cudin P. Degradation and restoration processes in crowns and fine roots of polluted montane Norway spruce ecosystems. Phyton. 1996. 36. № 3. P. 69-76.

16. Effect of Vehicular Lead Emissions on Biochemical Constituents of Leaves / S. Gupta, D. Bhattacharjee, J.K. Datta, S. Nayek, S. Satpati Poll. Res., 2009, 28 (2), 157-160.

17. Iusypiva T., Miasoid G. The Impact of Industrial Pollution with Toxic Gases on Stem Histological Parameters of Woody Plant Undergrowth under Conditions of the Southern Industrial Zone of the City of Dnipro, Ukraine. International Letters of Natural Sciences. Vol. 59. P. 62-71.

18. Impacts of ozone on forests: a European perspective. L. Skärby, H. Ro-Poulsen, A.R. Wellburn, L.J. Sheppard // New Phytol. 1998. 139. P. 109-122.

Надійшла до редколегії 14.09.2017 p. 